\title{
Dispute Resolution on Unauthorized Liquidation of Futures Positions at the Leading Stock Exchange in India: A Case Study ${ }^{1}$
}

\author{
Bezawada Brahmaiah $P h D$ \\ Professor of Finance \& Accounting \\ ICFAI Business School (IBS), Hyderabad, India \\ E-mail: brahmaiahb@ibsindia.org
}

\begin{abstract}
The paper studies compliances of Futures Trading rules and regulations of the Stock Exchange in the derivate market in India. The paper applies case method approach to study the trading practices of trading members of the Exchanges. It investigates the derivative market's misuses and abuses by the trading members of the Exchange. The paper provides guidance for the appropriate regulatory framework to curtail violations of rules and regulations in Indian derivative market, and enables the investor protection. The results may be generalized in the emerging markets. Hence, researchers are encouraged to study results further in other developed countries. The paper finds that these practices are not only violation of trading rules of the Stock Exchange but also unfair and unethical trading practices. The research findings and results may lack generalizability in a case study approach.
\end{abstract}

Keywords: Dispute Resolution, Arbitration, Futures Trading, Stock Exchanges.

I. Introduction

This paper is an appeal matter referred to the appellate tribunal by the Stock Exchange of India Ltd (SEBI20I0). This appeal has been preferred against the award passed by the arbitrators with regard to a dispute between Mr Prasad Reddy (Constituent and Applicant) and Zebra Securities Ltd, (Trading Member and Respondent) regarding squaring off the client's open positions in Futures segment by the trading member on account of margin short fall. The panel of arbitrators directed Zebra Securities Ltd (ZBL), the respondent to pay Rs 36.78 million to the applicant through the said award. Aggrieved and dissatisfied by the award, Zebra Securities Ltd, the trading member filed the Appellate Application at the Stock Exchange. (The Arbitration and Conciliation Act. 1996

\section{I.I Ground for the Appeal}

Appellant submits that the original panel of arbitrators had incorrectly and arbitrarily upheld its arbitration application, and directed them to pay Rs.36.78 million to Mr. Prasad Reddy, the respondent. The purported findings in the said impugned award are based on totally erroneous and untenable assumptions by ignoring the appellant's responses, submissions and facts of the case. Appellant further submits that the impugned award is unjust, unfair, untenable and liable to be and ought to be set aside. The original panel of arbitrators had not appreciated the functioning of the stock market, various rules, regulations, circulars etc of the Securities and Exchange Board of India (SEBI) and Stock Exchanges such as BSE and NSE for collection of margins, the real time facilities provided by the appellant to its clients. The appellant further submits that the impugned award is contrary to the pleadings of the parties and is deserves to be quashed and set aside, on reasons. The impugned award was based on the ipse dixit of the arbitrators. The arbitrators were bound to act and adjudicate according to the principles of natural law. But the award in question was bad in -law and deserves to be set aside. The impugned award is contrary to the principles of natural justice.

\section{I.2 Statement of Claim by the Appellant}

Zebra (hereinafter referred to as "Appellant") is a trading member (TM) registered with Stock Exchange of India Ltd. (SEI) having the SEBI Registration and is permitted to trade in all the segments of the Stock Exchange. It is headquartered in Bangalore and has physical presence in all major Indian cities. Appellant is a leading trading member in the country and the entire trading is completely online using advanced technology. The back office portal allows a client to check his profile details including details of bank account mapped to the trading account and other such personal information using which the account was opened. Mr Prasad Reddy, a constituent (hereinafter to be referred to as respondent) is registered with the appellant in the Cash, Futures \& Options, and Currency Derivatives segments.

I. This paper is based on an arbitration matter resolved at the leading stock exchange of India by the author. Names of client (Respondent), trading member, (Appellant), and Exchange were disguised to preserve confidentiality. The facts and circumstances were remained same to maintain originality of the case matter. The Arbitration mechanism of the Stock Exchange is framed under the Arbitration and Conciliation Act, 1996 of India. 


\section{I.3 Brief Description of the Dispute}

The account status of the respondent as on August 09, 2017 and the positions were

- 30,000 quantity of India Motors August 2017, Futures Series

- 30,000 quantity of India Motors September 2017 Futures series and

- 30,000 quantity of India Motors October 2017 Futures Series.

The quarterly financial results of India Motors Ltd were announced after market hours of August 09, 2017. There was a sharp fall in prices of India Motors Ltd Future Contracts on August I0, 2017. The mark to market (MTM) loss on account of sharp fall in prices of the said positions was to the tune of INR I4. 00 million. The loss increased during the day as the prices were falling and the mark to market (MTM) loss of August I0, 2017 was INR 32.76 million. Appellant squared off 75,000 shares of India Motors Futures consisting of 30,000 shares of India Motors August 2017 Futures Series, 30,000, shares of India Motors September 2017 Futures series and 15,000 shares of India Motors October 2017 Futures Series of the respondent's positions at 09:25 AM on August II, 2017 on account of shortfall in margins for trading day of August I0, 2017. Appellant submits that all the efforts were made to intimate the respondent about margin requirements and intentions of squaring off his positions for want of margins. SMS's regarding breach of margins was sent on August I0, 2017 and the "Funds" sections of the trading platform clearly show the margin requirements of the Respondent on a live basis. Web notifications on the trading terminal regarding shortage of margin were continuously shown to the Respondent; and the margin statement, which gave the Client an additional two hours between 07:30 AM and 09:30 AM to bring in additional funds to avoid any square off.

Only after receiving of all such segment wise files, the trading member can complete the trade process and send the margin statements to clients. The appellant generates margin statements post 09:00 PM on a daily basis. After completion of process at the back end at around 09:00 PM, the appellant emails the margin statements to all clients as daily practice. Appellant further submits that Rights and Obligations of Stock Brokers, Sub-Brokers and Clients as prescribed by SEBI and Stock Exchanges, are required to do trading as per the rights and obligations as prescribed by the SEBI.

\section{Statement of Defense by the Respondent}

Respondent submits that he has received margin statements, from appellant on potential shortfall of funds on August 9, 2017. Accordingly, respondent has arranged INR 7.00 million, through online transfer before 09:00 AM on August I0, 2017. After that the respondent has not received any communication from appellant on margin short fall until the morning of the August II, 2017. Appellant usually sends margin statements every day without fail, after the market closure of the day or before market opens on the next day. Respondent follows these emails to track the fund balance and arrange funds for any short fall in margins. Respondent has not received any margin statements or contract notes for August I0, 2017 until August II, 2017. Respondent received a SMS from appellant on August II, 2017 at around 09:15 AM for the shortfall of margins and immediately he logged into his email to find contract notes sent at 07:00 AM on the same day. He was in the process of mobilizing funds from his bank accounts such as HDFC Bank Ltd, State Bank of India and Axis Bank Ltd. Due to balance transfer limitations, he could transfer only rupees one million at a time from State Bank of India and rupees five million at a time from Axis Bank. Although he has the credit balance in his account with the appellant is coming down due to under performance of India Motors shares, there was no short fall of account until first quarterly results on August I0, 2017. The account went into debit balance in margins for the first time on August I0, 2017. Respondent submits that while he was in the process of arranging funds to transfer, appellant liquidated 78,000 shares of India Motors Ltd Futures in his account at market price. As the sell orders were placed at market price, the shares got executed at substantial lower prices causing the stock price to hit 52 week's low price. The bulk sale of shares at market price created pressure on the stock price and pushed down the prices of the stock significantly. This unwarranted sale has caused severe distress, and resulted huge financial loss to the respondent. At that time his account had several equity shares worth of about ten million rupees which are sufficient enough to cover the negative balances.

The email for the margin statement was sent by appellant only in the early hours at 07:44 AM on August II, 20I7. He took a note of the email at around 09:00 AM and initiated the process of money transfer, before which the appellant liquidated his long positions. This essentially gave only 90 minutes time to arrange for the margins shortfall, which was contrary to the guidelines prescribed and stipulated by the NSE. Appellant could have used his equity holdings as collateral to hold off any hasty sell off. Instead, appellant liquidated all his positions of Futures segment. He has one full day of August II, 2017 to arrange funds for the short fall in margins. As per point I.7.I of the guidelines, stock broker can liquidate the securities if the client fails to arrange the funds after a day's time for the client to arrange funds. In this case the margin short-fall was calculated by the end of day on August I0, 2017 and the liquidation was carried out in the early trading hours of next trading day on August II, 2017 without giving enough time as per the provisions of SEBI and NSE guidelines. The India Motors stock price was INR. 380/- per share, on closure of August I0, 2017 and price at the time of liquidation was INR 360/- per share. The appellant failed miserably to comply with the liquidation guidelines of NSE, in not providing sufficient time for the client to respond and arrange funds to support margin shortfall. Giving time till closure of market on August II, 2017 would have kept the margin short-fall almost at the level of the short fall on August IO, 2017. It is possible that appellant or its employees sold their shares and the same time either to buy the shares or short options at the same time to get guaranteed outcome for their personal transactions at the cost of his shares. Respondent requests a thorough investigation of possible foul play by the appellant in the derivative market. . In view of the 
development, respondent also requests the arbitration panel to advise the Stock Exchange and SEBI to investigate any possible malpractices involved in these transactions. Appellant was normally very punctual in sending margin statements on a daily basis. The fact that the communication was not sent on August I0, 2017 and that the appellant choose to communicate the margin statements at a short notice so gives scope to believe that he should not get an opportunity to go through the communication for making necessary arrangement for funds. It also makes him to believe that the communication is witheld intentionally so as to give appellant and its employees the opportunity to sell of these units. (SEBI 20I2)Respondent submits that appellant had enough time till the end of the day to ensure margin guidelines set by Stock Exchange. Having taken all these considerations, appellant could have avoided hasty sell-off at lowest price. Respondent contends that the appellant had no right to liquidate the positions. Therefore, Respondent pleads the arbitration panel to direct Appellant to refund INR 4I.35 million - towards the losses incurred by him. Respondent claimed INR. 36.35 million Towards losses incurred by him and INR 5.00 million towards mental agony, totaling INR 4I.35 million. Respondent requests panel of arbitrators to consider the interest on compensation from the day of his loss till realization of the award.

\section{Findings and Award of the Earlier Panel of Arbitrators}

The original panel of arbitrators observed that margin requirements are worked out on the basis of end of day closing prices of stocks. Admittedly, the margin statements would be ready later in the night and could be sent only by the next day. As such, the client could not be expected to work out the complex SPAN margin, dynamically and take appropriate corrective action. The respondent cannot set aside the responsibility to provide the margin statements promptly so that the clients can take the required action. The SMS messages sent by the respondent did not provide details regarding the extent of shortfall and the amounts required to make good the shortfall. . Since the applicant in this case was taking active steps for remitting funds promptly, it would be preposterous to consider it as a case of non-payment of the dues or shortfalls in margins. It is observed that the SMS message was sent as late as 09:25 AM on August II, 2017 urged the Applicant to remit the funds to avoid the danger of squaring off. At the very same time the Risk Management team of the Respondent had squared off the position. It, therefore, is surprising to note that that on one hand the respondent asked the applicant to replenish funds immediately, and simultaneously liquidated the position. The applicant had equities worth about INR 10.00 million in his account. Even if there was further erosion in the margins, the respondent could have exercised his lien on these securities to compensate the short fall in margins to that extent. It is therefore; felt that the respondent had acted in undue haste to liquidate the positions of client, causing him huge losses. Arbitration members had considered the highest quotes for the share during the contract periods, based on which, the sale value for 78,000 shares of India Motors worked out to INR 321.60 million. As against this, the respondent realized INR 284.82 million for liquidation of 78000 shares of India Motors.

\section{Analysis, Observations, Findings and Conclusions of Present Panel Arbitrators}

As per the submissions made by the appellant, it is observed that the cash balance available in account of respondent as on August 09, 2017 was INR 44.43 million and margins blocked for such position held by the respondent was INR 47.38 million. As a result of this crystallization of higher margin, the account of respondent with appellant moved to debit (negative) balance of (INR 2.94 million.). The financial position as on MTM losses based on the closing prices on August I0, 2017 was (INR 32.76 million) and Cash balance available in account as on August I0, 2017 was INR. 44. 43 million and net cash balance available in the account as on August 10, 2017 was INR II.67 million. The margin shortfall on closure of market as on August I0, 2017 (Daily Trading/settlement Day) was INR 30.50 million. This was due as on August I0, 2017 and has to be payable by the respondent (on T+I basis) on August II, 2017 and not on August I0, 2017. Margin payment day and Settlement day for MTM (T+I) was August II, 2017 not August I0, 20I7. This is evidenced and confirmed by the NSCCL Circular No 75/ 2017 dated July 05, 2017 on subject: F\&O Monthly Settlement Schedule for August 20I7(SEBI 2017).

It is very clear that initial margins and exposure margins are to be collected from the clients on upfront basis i.e., before taking positions in the futures market (stocks futures /index futures). Initial margin includes for two days $\mathrm{VaR}$ to compensate the one day delay (one day time given to client) for collection of MTM. MTMs are collected on T+I day basis. As per National Securities Clearing Corporation Ltd (NSCL) Circular No 75/ 2017 dated July 05, 2017, the August 10, 2017 was the daily settlement date for the trading day of August, 09, 2017 and the August II, 2017 was the settlement date for the trading date of August 10, 2017. The appellant and its team members in Compliance Department and Risk Management either ignored these margins rules, regulations, settlement obligations and settlement days or not aware of the same. It seems appellant confused on different margin calculations and collections management for Futures and Options segment. The margins rules and regulations are very clear on calculations, collections and timing of collections. Appellant instead of following NSE's margin rules and regulations, and adhering to the schedule for collection and settlement obligations, appellant was relying on its arguments on other issues such as terms of agreement and clauses of disclosure requirements Client has to make payment on $\mathrm{T}+\mathrm{I}$ day, respondent has time to make margin payment (short fall of margin/ Mark to Market losses) till August II, 2017 provided appellant informs the same to the respondent. It is noticed that appellant didn't send the contract notes, margin statements and margin obligations to the respondent after closure of the market on August I0, 2017 but these were sent to him in the early hours of August II, 2017. 
Risk department of the trading member without knowing the settlement obligations, payment obligations and settlement cycle i.e., and without informing the respondent, liquidated all the positions of respondent within ten minutes of market opening since it has access and control over the client's open positions and its trading system. This was nothing but an unauthorized trade. Appellant indulged in unauthorized trades in the account of the respondent. These are leveraged transactions which are created and traded with 20 to 30 per cent of the exposure or traded value. Appellant had squared off 75,000 shares of India Motors hurriedly and recklessly within ten minutes of the market opening. As result of the heavy selling at the counter, the price of India Motors crashed and it hit 52 week's low (Yearly Low) and respondent suffered huge losses. Trading member has to take the full responsibility of meeting margin obligations on real time basis after having opted for trading membership in Futures and Options segment.

Trading member is primarily subjected to the rules and regulations of the Stock Exchange at first level and Indian Contract Act 1872 would apply if there no rules and regulations on these issues. Contrary to this, the appellant claims that it had adhered to the terms and conditions and clauses in the disclosure requirements. It is not tenable and does not form valid grounds or any substance in this matter. All trading members are subject to Stock Exchange's rules and regulations at first level and therefore, any contrary terms and clauses in the agreements to the NSE rules and regulations, the terms will not have any validity and substance.

The issues before the present panel of arbitrators is whether the appellant is within its rights to square off the open position of the client on account of shortage of margins or not. It is concluded that Appellant is not justified in liquidation of respondent's open positions. As per extant rules and regulations of the Stock Exchange, respondent had time till August II, 2017 to meet the MTM margin obligations belonging to the trading day of August I0, 20I7. Hence, there was no question of default in pay in obligations by the respondent. Therefore, appellant doesn't have the right to square off the position of the respondent. The Tribunal did not consider the compensation of INR .5 .00 million towards mental agony as this is not under the jurisdiction of this tribunal. While calculating the losses and compensation, the original panel of arbitrators had taken the highest quotes for the scrip during the contract periods, based on which, the sale value for 78000 quantities of India Motors. The tribunal is of the opinion and view that it is difficult for seller to sell at highest price of the series/month as well as it is difficult for buyer to buy at the lowest price of the series/month. Occasionally, liquidations and square off takes place at lowest prices as these were sold by trading members not by investors/clients. Therefore, we are taking average closing/settlement price which is arrived by adding highest closing/settlement price and lowest closing/settlement price of the series/month and the same is divided by two is considered. The respondent suffered a loss of INR. 28.95 million On account of unauthorized trading indulged by the appellant. Therefore, this loss has to be borne by the appellant, and the same has to be reimbursed to the respondent on the principles of equity, fairness and natural justice.

\section{Recommendation and Award}

In view of the foregoing submissions, hearings, and arguments of the both parties, and on the basis our findings and conclusions, the loss incurred by the respondent on account of unauthorized liquidation has to be borne by the appellant. Therefore, the Panel of Arbitrators passed following award. The award passed by the original panel of arbitrators is quashed and set aside. The appeal filed by the appellant is dismissed. The appellant, Zebra Securities Ltd is directed to pay INR 28. 95 million with an interest rate of 12 per cent per annum for the delayed period i.e., from the date of the payout for squaring off the transaction day

\section{References}

SEBI. (20I0). Arbitration Mechanism in Stock Exchanges. No. CIR/MRD/DSA/29/, I-4.

The Arbitration and Conciliation Act. 1996, I-26.

SEBI. (20I2). Rights and Obligations of Stock Brokers, Sub Brokers and Clients Issued by the SEBI, Mu2.mbai, I-I5.

SEBI. (2017). Prevention of Unauthorized Trading by Stock Brokers, September 26,pp. I-2.

\section{Copyrights}

Copyright for this article is retained by the author(s), with first publication rights granted to the journal. This is an openaccess article distributed under the terms and conditions of the Creative Commons Attribution license (http://creativecommons.org/licenses/by/4.0/). 